\title{
The Impact Of Religiously Affiliated Universities And Courses In Ethics And Religious Studies On Students' Attitude Toward Business Ethics
}

\author{
Charles Comegys, Merrimack College, USA
}

\begin{abstract}
Unfortunate unethical events are continuing in the business arena and now more than ever these business judgmental shortcoming focus attention on the ethics of business executives. Thus, colleges and universities must continue to address business ethics as they prepare and train the next generation of executives. Educational institutions should be concerned with the environmental factors and curricular additions or modifications that may impact their graduating students who will become future business leaders. The purpose of this study is to examine students' attitude toward business ethics and to determine: (1) if attending a religiously affiliated educational institution impact these ethical attitudes, and (2) if completing ethics courses or religious studies courses effects these ethical attitudes. There is evidence to suggest that students attending religiously affiliated colleges and universities may have attitudes about business that are more ethical. Additionally, the argument that ethics can be taught is supported. Business majors who had completed at least one ethics course were found to have a more strict ethical perspective. No differences were found with non-business majors who had one or more ethics courses compared to those students that did not complete such a course. Results also indicated that business majors with one or more religious studies course were slightly more ethical in their outlooks. The influence of religious studies courses on ethical attitudes was far greater for nonbusiness majors. The implications are that ethical education and institutional climate may play a role in effectively shaping students attitudes about business ethics. This study suggests that completing ethics courses for business majors and religious studies courses for non-business majors may impact undergraduate students' attitudes towards business ethics. Colleges and universities must continue to focus on the challenges and address opportunities to achieve success in business ethics education.
\end{abstract}

Keywords: Business Ethics, Impact of Academic Major on Business Ethics Attitudes, Impact of Attending Religious Affiliated University on Business Ethics Attitudes, Impact of Ethics Courses on Business Ethics Attitudes, Impact of Religious Courses on Business Ethics Attitudes

\section{INTRODUCTION}

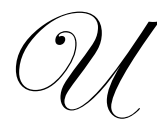

nfortunate unethical events are continuing in the business arena and now more than ever these business judgmental shortcoming focus attention on the ethics of business executives. The New York Times (2009) reporting on the Bernard L. Madoff Investment Securities multibillion-dollar Ponzi scheme, indicated that according to court filings by the trustee charged with recovering assets for investors defrauded by Madoff, he used his firm's investment funds to pay for private planes, yachts, country club memberships, and real estate for himself as well as for friends, employees, and family members. The Washington Post (2006) reported that the FBI was pursuing criminal conspiracy charges against executives at a New York software maker, Converse Technology Inc., as well as against 44 other companies for backdating stock option awards. The Securities and Exchange Commission is also examining 80 companies. The Wall Street Journal in March 2006 questioned the 
timing of stock option awards at six companies including UnitedHealth, Converse Technology, and Affiliated Computer Services. The Journal further reported on June $16^{\text {th }}$ that Microsoft awarded stock grants to employees at monthly lows during the 1990's. On this same day Home Depot also disclosed that some of their executives had received stock options with the exercise prices below the market price on the date of issue.

According to Institutional Shareholder Services (2006) by June at least 50 companies including Apple Computer Inc. and Monster Worldwide Inc. have disclosed criminal, regulatory or internal investigations into the backdating and/or manipulating the timing of stock option grants to senior executives. This deceitful practice using corporate position and power continues the litany of executive scandals in recent years at Enron Corp., WorldCom Inc., Tyson, K-Mart, Aldelphia, Tyco, the law firm of Milberg Weiss Bershad \& Schulman, Arthur Andersen, Boston’s Big Dig contractor Modern Continental Construction Co., and more recently Hewlett-Packard.

As these and other unethical misdeeds continue in the business world, a great deal of attention on the ethics of business executives is justified. Thus colleges and universities must continue to address business ethics as they prepare and train the next generation of executives. Educational institutions should be concerned with environmental factors and curricular changes or modifications that may impact their graduating students and our future business leaders. For example, the George Washington University School of Business recently hosted an AACSB Ethics and Governance Conference to assist business schools in assessing leadership roles in ethics. The purpose of the event was to explore the future of business ethics and address opportunities and challenges to achieve success in ethics through education. Although the Association to Advance Collegiate Schools of Business (AACSB) has supported the teaching of business ethics as early as the 1980s, they are now stepping up their efforts in this area. The Ethics Education Task Force created in June 2004 by AACSB published a report on "Ethics Education in Business Schools." In the forward to that report, Susan Philips challenged business educators by her statement that "the crisis in business ethics is not only a challenge for companies but also an opportunity to strengthen management education" (Report of the Ethics Education Task Force, 2004, p.7). AACSB's renewed resolve concerning ethics education in the curriculum is further revealed in the Task Force Report statement that business schools must "renew and revitalize their commitment to the centrality of ethical responsibility at both the individual and corporate levels in preparing business leaders for the twenty-first century" (Report of the Ethics Education Task Force, 2004, p.9). AACSB continued its firm commitment to ethics education with the launch of its new Ethics Education Resource Center hosted on its website.

Although there is a plethora of studies in the literature investigating the influences on ethical perceptions of students by a multitude of factors such as cross-cultural and demographic variables including age, gender, and undergraduate major, there is a void in the research concerning the impact on students' ethical attitudes for those attending religiously affiliated educational institutions. Additionally, there is little evidence assessing the impact of completing religious studies courses. Further, the evidence concerning ethics courses in the curriculum remains mixed. This study, therefore, is designed to understand if the university's religious affiliation results in differences in students' ethical attitudes, and if there is a relationship between the completion of ethics or religious studies courses and students' attitudes towards business ethics.

\section{LITERATURE REVIEW}

\section{Impact of Ethics Courses}

The literature exploring the impact of ethics courses on students' ethical attitudes present mixed findings. For example, Conroy and Emerson (2004) found that completion of ethics classes had little influence on students' ethical attitudes. They found that only two of their 25 ethical dimensions were significant predictors of ethical attitudes of students. Tanner and Cudd (1999) reported that the impact of taking ethics courses was limited or short lived. The findings of Luthar, DiBattista and Gautschi (1997) however provide strong support for exposure to ethical education. Other studies provide insignificant or mixed results (Murphy and Boatright 1994; Borkowski and Ugras 1992; Arlow 1991; Mayer 1988; Stevens 1984; and Boyd 1982).

In another study by Murphy and Boatright (1994) students who had completed business ethics courses were compared to students who had taken courses which included business ethics among many topics. The two groups 
ranked ethical issues differently. Results suggest that a course in business ethics can have a positive effect on students' abilities to identify the presence of ethical issues and students' sensitivity to ethical issues can be influenced by formal instruction in business ethics.

Rest (1988) concluded that there is evidence that ethical education can influence the development of moral perspectives among students. The findings reported by Luthar and Karri ( 2005) highlighted the value of ethical education and concluded that exposure to ethics in the curriculum had a significant positive effect on undergraduate students' perceptions of both the ideal ethical climate and the current climate. In this study, exposure to ethics in the curriculum was measured by completion of ethics courses as well as exposure to ethical issues in the students' other courses.

Lopez, Rechner and Olson-Buckanan (2005) reported findings that formal business education decreased business students' tolerance for unethical behavior. The students in this sample were exposed to a business curriculum that had ethics integrated throughout rather than having a particular ethics course(s) for students to complete.

\section{Impact of Religion \& Religion Courses}

Conroy and Emerson (2004) concluded that taking religion or theology courses had minimal impact on students' ethical attitudes. They did find that religiosity, defined as church attendance or religion was "very important" in making daily decisions, was a significant predictor of ethical attitudes. Albaum and Peterson (2006) also concluded that business students who considered themselves to be "very religious" were slightly more ethically inclined compared to those business students who reported being "less religious." Several other studies also confirmed that college students' religiosity had significant but varying influence on their attitudes concerning business ethics (Kennedy and Lawton 1998, Terpstra, Rozell, and Robinson 1993, and Shepard and Hartenian 1990). A study by Smith and Oakley (1996) reported mixed religiosity effects and Agle and Van Buren (1999) concluded no significant religiosity impact on business ethics attitudes.

Additionally, Lin (1999) asked Taiwanese students their perception of the influence of religion on ethical standards. He reported that almost 32 percent of the respondents indicated "not much influence," 54.7 percent cited "somewhat influential, " and only 13.3 percent responded "very influential." When the sample was asked if they considered themselves "ethically minded," Lin's research recorded 21.7 percent responding "totally true" and 72.3 percent "somewhat true."

\section{METHODOLOGY}

\section{Sample and Data Collection}

A questionnaire was completed by a quasi random convenience sample of undergraduate students at six different colleges and universities located in the northeast region of the United States. Each institution's total undergraduate populations size was used to determine the proportional representative sample size required from each location. Intercepts at high student traffic areas, such as in student cafeterias and student campus centers, were used to accomplish survey completions. The survey was self-administered in order to eliminate any interviewerevaluation apprehension by the respondents (Hill 1995) and a free candy bar incentive was also employed. Respondent anonymity was protected by having completed questionnaires deposited directly into a survey response box. Completed questionnaires were collected from 780 undergraduate students. The data were gathered during a two week period in the fall of 2004.

The survey consisted of the Attitude Towards Business Ethics Questionnaire (ATBEQ - see Exhibit 1) (Preble and Reichel 1988) as well as questions gathering appropriate demographic information including gender, age, major area of study, approximate overall GPA, and the number of ethics and religious studies courses completed in college. 
The ATBEQ was originally developed by Neumann and Reichel based on "Values Clarification Exercises" of Stevens (1979) and was published in the work of Preble and Reichel in 1988. The questionnaire consists of thirty statements with a five point Likert scale for each item ranging from 1 "disagree strongly to 5 "agree strongly." The statements are "related to various business philosophies like Social Darwinism, Machiavellianisn, Objectivism, and Ethical Relativism" (Preble and Reichel, 1988, p.943).

This sample included 53.9 percent (417) women and 45.7 percent (354) men. Freshmen made up 27 percent of the sample (209), sophomores accounted for 29.2 percent (226), junior respondents (212) were 27.2 percent, and 16.4 percent were seniors. Major area of study revealed that 27.4 percent (214) were in business, 42.7 percent studied liberal arts (328), another 23.2 percent were enrolled in science and engineering as a major while an undecided group of 45 accounted for the final 5.8 percent. The average age of the sample was found to be 19 years and 8 months. The average GPA was reported to be 3.14 on a 4 point scale. Thirty-one percent (239) had completed from 1 to 5 ethics courses in college. With respect to religious studies courses completed, 32.2 percent (239) had taken from 1 to 10 such courses. Sixty-eight percent of the students (530) attended a private institution while 32 percent (250) matriculated at a public college or university. Students attending one of the two religiously affiliated school comprised 26.7 percent (208) of the sample, while 73.3 (572) of the respondents were from a non-religiously affiliated institution. Sixty-nine percent (533) of the responding students had not completed an ethics course.

The completion of a single ethics course was recorded by 20 percent (156) of the sample and 10.7 percent (83) had taken two to five ethics courses in their academic careers to date. Religious studies courses completed ranged from one to ten with 13.2 percent (103) having finished a single course, 15.5 percent (121) completed two religion courses, and only 3.1 percent registered having completed three or more courses. Sixty-eight percent (523) had never completed a religious studies course. Sixty-one percent (469) of the sample came from one of the three schools with total undergraduate enrollment ranging from 6,200 to 17,000 students. The remaining 39.9 percent (311) were students from schools with total undergraduate enrollments ranging from 1,700 to 5,500.

\section{RESULTS AND ANALYSIS}

Table 1 presents the mean scores for the total sample by religiously and non-religiously affiliated educational institutions for nine ATBEQ ethics statements. For the items listed, the mean score differences were found to be statistically significantly at the 0.05 level or better.

Table 1: Total Sample by Religiously and Non-Religiously Affiliation

\begin{tabular}{|c|c|c|c|c|}
\hline & Ethics Statement & Variables & Mean & Sig. (2-tailed) \\
\hline \multirow[t]{2}{*}{1} & A person who is doing well in business does not have to & Non-religiously affiliation & 1.94 & .001 \\
\hline & worry about moral problems. & Religiously affiliation & 1.71 & \\
\hline \multirow[t]{2}{*}{2} & \multirow{2}{*}{$\begin{array}{l}\text { Business decisions involve a realistic economic attitude } \\
\text { and not a moral philosophy. }\end{array}$} & Non-religiously affiliation & 2.98 & .036 \\
\hline & & Religiously affiliation & 2.80 & \\
\hline \multirow[t]{2}{*}{3} & \multirow[t]{2}{*}{ Moral values are irrelevant to the business world. } & Non-religiously affiliation & 2.31 & .000 \\
\hline & & Religiously affiliation & 1.99 & \\
\hline \multirow[t]{2}{*}{4} & \multirow[t]{2}{*}{ "Business ethics" is a concept for public relations only. } & Non-religiously affiliation & 2.40 & .017 \\
\hline & & Religious affiliation & 2.23 & \\
\hline \multirow[t]{2}{*}{5} & \multirow{2}{*}{$\begin{array}{l}\text { While shopping at the supermarket, it is appropriate to } \\
\text { switch price tags or packages. }\end{array}$} & Non-religiously affiliation & 2.02 & .010 \\
\hline & & Religiously affiliation & 1.80 & \\
\hline \multirow[t]{2}{*}{6} & \multirow[t]{2}{*}{ A business person can't afford to get hung up on ideals. } & Non-religious affiliation & 2.67 & .004 \\
\hline & & Religiously affiliation & 2.44 & \\
\hline \multirow[t]{2}{*}{7} & \multirow{2}{*}{$\begin{array}{l}\text { If you want a specific goal, you have got to take the } \\
\text { necessary means to achieve it. }\end{array}$} & Non-religiously affiliation & 3.70 & .007 \\
\hline & & Religiously affiliation & 3.46 & \\
\hline \multirow[t]{2}{*}{8} & \multirow[t]{2}{*}{ True morality is first and foremost self-interested. } & Non-religiously affiliation & 2.78 & .031 \\
\hline & & Religiously affiliation & 2.58 & \\
\hline \multirow[t]{2}{*}{9} & \multirow[t]{2}{*}{ Self-sacrifice is immoral. } & Non-religious affiliation & 2.40 & .044 \\
\hline & & Religiously affiliation & 2.24 & \\
\hline
\end{tabular}


All of the statements except (\#7): "If you want a specific goal, you have got to take the necessary means to achieve it." reveal that students attending a religiously affiliated educational institution expressed more disagreement with these expressions than those students attending a non-religiously affiliated college/university. In the case of statement (\#7), students attending religiously affiliated schools recorded less agreement than those at non-religiously affiliated schools.

Table 2 illustrates the four ethical statements where significant differences were found between business majors attending religiously affiliated and non-religiously affiliated schools.

Table 2: Business Majors by Religiously and Non-Religiously Affiliation

\begin{tabular}{llcc}
\hline \multicolumn{1}{c}{ Ethics Statement } & \multicolumn{1}{c}{ Variables } & Mean & Sig. (2-tailed) \\
\hline Business decisions involve a realistic economic attitude & Non-religiously affiliation & 2.92 & .023 \\
and not a moral philosophy. & Religiously affiliation & 2.59 & .000 \\
\hline Moral values are irrelevant to the business world. & Non-religiously affiliation & 2.38 & 1.81 \\
& Religiously affiliation & 2.46 & .000 \\
\hline "Business ethics" is a concept for public relations only. & Non-religiously affiliation & 1.97 & .036 \\
& Religiously affiliation & 2.01 & 1.74 \\
\hline While shopping at the supermarket, it is appropriate to & Non-religiously affiliation & & \\
switch price tags or packages. & Religiously affiliation & & \\
\hline
\end{tabular}

In each case above business majors at religiously affiliated schools expressed less agreement with these unethical statements than business students attending non-religiously affiliated institutions.

Table 3 shows the comparisons for six ethical statements where significant differences were found between non-business students attending religiously and non-religiously affiliated institutions.

Table 3: Non-Business Majors by Religiously and Non-Religiously Affiliation

\begin{tabular}{|c|c|c|c|}
\hline $\begin{array}{l}\text { Ethics Statement } \\
\end{array}$ & Variables & Mean & Sig. (2-tailed) \\
\hline \multirow{2}{*}{$\begin{array}{l}\text { A person who is doing well in business does not have to } \\
\text { worry about moral problems. }\end{array}$} & Non-religiously affiliation & 1.94 & \multirow[t]{2}{*}{.000} \\
\hline & Religiously affiliation & 1.61 & \\
\hline \multirow[t]{2}{*}{ Moral values are irrelevant to the business world. } & Non-religiously affiliation & 2.28 & \multirow[t]{2}{*}{.044} \\
\hline & Religiously affiliation & 2.07 & \\
\hline \multirow[t]{2}{*}{ A business person can't afford to get hung up on ideals. } & Non-religiously affiliation & 2.63 & \multirow[t]{2}{*}{.005} \\
\hline & Religiously affiliation & 2.36 & \\
\hline \multirow{2}{*}{$\begin{array}{l}\text { If you want a specific goal, you have got to take the } \\
\text { necessary means to achieve it. }\end{array}$} & Non-religiously affiliation & 3.73 & \multirow[t]{2}{*}{.001} \\
\hline & Religiously affiliation & 3.36 & \\
\hline \multirow[t]{2}{*}{ True morality is first and foremost self-interested. } & Non-religiously affiliation & 2.74 & \multirow[t]{2}{*}{.000} \\
\hline & Religiously affiliation & 2.37 & \\
\hline \multirow[t]{2}{*}{ Self-sacrifice is immoral. } & Non-religiously affiliation & 2.38 & \multirow[t]{2}{*}{.009} \\
\hline & Religiously affiliation & 2.14 & \\
\hline
\end{tabular}

At religiously affiliated schools, non-business majors displayed statistically significant differences with the six ethics statement compared to their counterparts at non-religiously affiliated institutions. These non-business majors at religiously affiliated schools expressed less agreement with each statement.

With regard to the question of whether exposure to ethics education in its present form impacts students' attitudes toward business ethics, of interest is that the comparison of means for non-business majors who have completed one or more ethics courses with those who had not completed any ethics courses yielded no significant differences on any of the ethical dimensions.

However, Table 4 illustrates the six ethical statements with significantly different mean scores for business students who have completed one or more ethics courses compared to those with no ethics courses completed. 
Table 4: Business Majors With and Without Ethics Courses

\begin{tabular}{llcc}
\hline \multicolumn{1}{c}{ Ethics Statement } & \multicolumn{1}{c}{ Variables } & Mean & Sig. (2-tailed) \\
\hline $\begin{array}{l}\text { Moral values are irrelevant to the business } \\
\text { world. }\end{array}$ & $\begin{array}{l}\text { One or more Ethics Courses Completed } \\
\text { No Ethics Courses Completed }\end{array}$ & 2.04 & .039 \\
\hline $\begin{array}{l}\text { "Business ethics" is a concept for public } \\
\text { relations only. }\end{array}$ & $\begin{array}{l}\text { One or more Ethics Courses Completed } \\
\text { No Ethics Courses Completed }\end{array}$ & 2.33 & .11 \\
\hline $\begin{array}{l}\text { The main interest of shareholders is maximum } \\
\text { return on their investment. }\end{array}$ & One or more Ethics Courses Completed & 3.46 & .007 \\
\hline $\begin{array}{l}\text { If you want a specific goal, you have got to } \\
\text { take the necessary means to achieve it. }\end{array}$ & One or more Ethics Courses Completed & 3.83 & .016 \\
\hline The business world has its own rules. & No Ethics Courses Completed & 3.50 & .032 \\
& One or more Ethics Courses Completed & 3.09 & .009 \\
\hline $\begin{array}{l}\text { You can judge a person according to his work } \\
\text { and his dedication. }\end{array}$ & One or more Ethics Courses Completed & 3.48 & 3.50 \\
& No Ethics Courses Completed & 3.20 & .033 \\
\hline
\end{tabular}

Statements 1:"Moral Values are irrelevant to the business world." and 2:" "Business ethics is a concept for public relations only." recorded more disagreement by business majors who had completed at least one ethics course. Statements 3: "The main interest of shareholders is maximum return on their investment." statement 4: "If you want a specific goal, you have got to take the necessary means to achieve it." and statement 6: "You can judge a person according to his work and his dedication." All show a statistically higher mean score for those who have completed an ethics course than those who have not. This indicates more agreement with each statement. The final statement 5: "The business world has its own rules." was agreed to by more business majors who had not completed an ethics course than those who had. Those business students with at least one ethics courses had more neutral scores.

The questions of whether religious studies education impacts students attitudes toward business ethics, Table 5 shows the two ethics statements found significant when comparing business students who have completed religious studies courses with those business students who have not completed such courses. In each case business students who have completed one or more religious studies courses expressed more disagreement with the statements that "Moral values are irrelevant to the business world" and "Business ethics is a concept for public relations only."

Table 5: Business Majors With and Without Religious Studies Courses

\begin{tabular}{lllc}
\hline \multicolumn{1}{c}{ Ethics Statement } & \multicolumn{1}{c}{ Variables } & Mean & Sig. (2-tailed) \\
\hline Moral values are irrelevant to the & One or more Religious Studies Courses Completed & 2.00 & \\
business world. & No Religious Studies Courses Completed & 2.29 & .046 \\
\hline "Business ethics" is a concept for & One or more Religious Studies Courses Completed & 2.09 & \\
public relations only. & No Religious Studies Courses Completed & 2.41 & .018 \\
\hline
\end{tabular}

Significant differences were found for non-business majors with one or more religion courses. More disagreement (significantly lower mean score were displayed) with the five ethics statements shown in Table 6.

Table 6: Non-Business Majors With and Without Religious Studies Courses

\begin{tabular}{llcc}
\hline \multicolumn{1}{c}{ Ethics Statement } & \multicolumn{1}{c}{ Variables } & Mean & Sig. (2-tailed) \\
\hline $\begin{array}{l}\text { A person who is doing well in } \\
\text { business does not have to worry } \\
\text { about moral problems. }\end{array}$ & $\begin{array}{l}\text { One or more Religious Studies Courses Completed } \\
\text { No Religious Studies Courses Completed }\end{array}$ & 1.64 & 1.97 \\
\hline $\begin{array}{l}\text { Moral values are irrelevant to the } \\
\text { business world. }\end{array}$ & $\begin{array}{l}\text { One or more Religious Studies Courses Completed } \\
\text { No Religious Studies Courses Completed }\end{array}$ & 2.08 & 2.30 \\
\hline $\begin{array}{l}\text { The lack of public confidence in } \\
\text { the ethics of business people is }\end{array}$ & One or more Religious Studies Courses Completed & 2.54 \\
not justified. & No Religious Studies Courses Completed & 2.78 & .000 \\
\hline $\begin{array}{l}\text { True morality is first and foremost } \\
\text { self-interested. }\end{array}$ & One or more Religious Studies Courses Completed & 2.36 & .006 \\
\hline Self-sacrifice is immoral. & No Religious Studies Courses Completed & 2.78 & .000 \\
\hline & One or more Religious Studies Courses Completed & 2.16 \\
\end{tabular}




\section{DISCUSSION}

Based on our sample of respondents, there is evidence to suggest that students attending religiously affiliated colleges and universities may have more ethically inclined attitudes about business. Nine of the 30 ethical statements were found to be significantly different. The direction of responses for students attending religiously affiliated institutions in all cases was leaning toward a more ethical inclination. This finding held true for both business majors ( 4 of 30 ethical statement found significantly different) as well as for non-business majors (6 of 30 statements) compared to students at non-religiously affiliated educational institutions. This result may be explained by self-selection in that students with a more in depth religious and ethical background seek attendance at religiously affiliated schools. The religious and ethically orientated climate at such institutions may influence the attitudes of these students. It seems logical that students with a higher religiosity quotient may attend religiously affiliated institution. This is consistent with the finding of Conroy and Emerson (2004) and Albaum and Peterson (2006).

This study's findings provide some evidence to support the argument that ethics can be taught. Business majors who had completed at least one ethics course produced significantly different mean scores on six of the 30 statements suggesting they had a more strict ethical perspective. No differences were found with non-business majors who had one or more ethics courses compared to those students that did not complete such a course.

Two items indicated that business majors with one or more religious studies course were slightly more ethically oriented in their outlooks. The influence of religious studies courses on ethical attitudes was far greater for non-business majors, where in five of the 30 statements reported the mean score was significantly different from those who had not completed a religion course.

This study reveals that ethical education and institutional climate may play a role in effectively shaping students attitudes about business ethics. Completion of ethics courses by business majors and religious studies courses by non-business major may impact undergraduate students' attitudes towards business ethics.

\section{FUTURE RESEARCH}

Several areas are in need of future research. First, there is a need to replicate this study. Also, an investigation of whether students who attend religiously affiliated school have higher religiosity quotients may yield additional evidence concerning their ethical inclination and disapproval of unethical behavior. Additionally, there is a need to further investigate the ethical orientation of students attending business schools with integrated ethical programs as well as institutions with an overall ethically integrated curriculum.

Wesley Cragg (1997) stated:

... an institution or faculty seriously committed to values education should begin by committing itself to the identification and exploration of the values implicit in the materials, theories, cases, research and pedagogical strategies that inform the structure and content of the teaching curriculum. For it is here that the educational process impacts directly and powerfully on the lives of students and their mentors.

As the managers of the future continue to be educated, it is imperative that strong exposure to examining and understanding ethical issues in business be a part of that educational process. It has been estimated that there are over 500 business ethics courses offered by US educational institutions and about ten percent of US business schools do not offer any ethics education or training (Stark 1993). Only one third of AACSB accredited business schools have a stand alone course in ethics (Mitroff \& Swanson 2004). Educational institutions must understand how to most effectively incorporate ethical issues into the curriculum and into the overall educational environment. 


\section{AUTHOR INFORMATION}

Charles Comegys, Ph.D. is Ciejek Chair of Business with the Francis E. Girard School of Business \& International Commerce at Merrimack College, North Andover, Massachusetts, USA. Dr. Comegys' case studies have appeared in textbooks and his articles appear in numerous journals. He has served on the Board of Directors of the Marketing Research Association, and the Board of Directors of the Marketing Educators' Association. Dr. Chuck Comegys has also been President of the Boston Chapter of the American Marketing Association and served on the AMA's International Board of Directors.

\section{REFERENCES}

1. $\quad$ Agle, B.R., \& H.J. Van Burne (1999). "God and Mammon: The modern relationship." Business Ethics Quarterly, 9, 563-582.

2. Albaum, G., \& R.A. Peterson (2006). "Ethical Attitudes of Future Business Leaders: Do They Vary by Gender and Religiosity?" Business \& Society 45 (3), 300-321.

3. Arlow, P. (1991). "Characteristics in college students' evaluations of business ethics and corporate responsibility." Journal of Business Ethics, 10, 63-69.

4. $\quad$ Bok, D. (1976). "Can ethics be taught?" Change, (October), 26-30.

5. Borkowski, S.C. \& Y.J. Ugras (1992). "The ethical attitudes of students as a function of age, sex, and experience." Journal of Business Ethics, 11, 63-69.

6. Conroy, S.J., \& T.L.N. Emerson (2004). "Business Ethics and Religion: Religiosity as a Predictor of Ethical Awareness among Students.” Journal of Business Ethics, (50), 383-396.

7. Ethics Education Task Force to AACSB International, Ethics Education in Business Schools (2004.) St. Louis, MO AACSB International.

8. Forelle, C. \& J.Bandler (2006). "The Perfect Payday; Some CEOs reap millions by landing stock options when they are most valuable; Luck - or something else?" The Wall Street Journal, (Eastern edition). New York: March 18, 2006. p. A1.

9. (2006). "During 1990s, "Microsoft Practiced Variation of Options Backdating" The Wall Street Journal, (Eastern edition). New York: June 16, 2006. p. A1.

10. Glenn, J.R. (1992). "Can a business and society course effect the ethical judgment of future managers?" Journal of Business Ethics, 11(3), 217-224.

11. Hill, R. P. (1995). "Researching Sensitive Topics in Marketing - The Special Case of Vulnerable Populations." Journal of Public Policy \& Marketing, 14 (1), 143-49.

12. Institutional Shareholder Services (2006). "An Investor Guide to the Stock Option Timing Scandal," (July), $1-7$.

13. Izzo, G. (2000). "Compulsory ethics education and the cognitive moral development of salespeople: A quasi-experimental assessment." Journal of Business Ethic, 28(3), 223-241.

14. Johnson, C. (2006.) "3 Charged As Probe Into Options Widens; FBI Pursuing Cases of Illegal Stock Profits.” The Washington Post, (August 10), 1.

15. Kennedy, E.J., \& L. Lawton (1998). "Religiousness and Business Ethics.” Journal of Business Ethics, 17, 163-175.

16. Lin, C.Y. (1999). “A Comparison of Perceptions About Business Ethics in Four Countries.” Journal of Psychology, 133 (6), 641-656.

17. Luthar, H.K., R.A. DiBattista, \& T. Gautschi (1997). "Perception of What the Ethical Climate is and What it Should be: The Role of Gender, Academic Status, and Ethical Education." Journal of Business Ethics, (16), 205-217.

18. Luthar, H.K. \& R. Karri (2005). "Exposure to Ethics Education and the Perception of Linkage Between Organizational Ethical Behavior and Business Outcomes." Journal of Business Ethics, (61), 353-368.

19. Lopez, Y.P., P.L. Rechner, \& J.B. Olson-Buchanan (2005). "Shaping Ethical Perceptions: An Empirical Assessment of the Influence of Business Education, Culture, and Demographis Factors." Journal of Business Ethics, (60), 341-358.

20. Mayer, J. (1988). Themes of social responsibility: A survey of three professional schools.” Journal of Business Ethics, 7, 316. 
21. Mitroff, I. \& D. Swanson (2004). "An Open Letter to the Deans and the Faculties of American Business Schools: A Call for Action." The Academy of Management News, (35) 7-8.

22. Murphy, P.R. \& J.R. Boatright (1994). "Assessing the effectiveness of instruction in business ethics: A longitudinal analysis." Journal of Education for Business, 69, 326.

23. Okleshen, M. \& R. Hoyt (1996). "A cross cultural comparison of ethical perspectives and decision approaches of business students: United States of America versus New Zealand. Journal of Business Ethics, 15, 537-549.

24. Picard, I.H. (2009) "Records Show How Madoff Used Firm as 'Piggy Bank"” The New York Times, (May 6), 1.

25. Preble, J. F. \& A. Reichel (1988). "Attidudes Towards Business Ethics of Future Managers in the US and Israel.” Journal of Business Ethics, (12), 941-949.

26. Salmans, S. (1987). "Suddenly business schools tackle ethics." New York Times Education Life, August 2, 64-69.

27. Shepard, J.M., \& L.S. Hartenian (1990). "Egoistic and ethical orientations of university students toward work-related decisions." Journal of Business Ethics, 10, 303-310.

28. Smith, P.L., \& E.F. Oakley (1996). "The value of ethics education in business school curricula." College Students Journal, 30, 274-283.

29. Stark, A. (1993). "What's the matter with business ethics?" Harvard Business Review, (May-June), 38-48.

30. Stevens, G. (1984). "Business ethics and social responsibility: The responses of present and future managers." Akron Business and Economics Review, 15, 6-11.

31. Tanner, J. \& M. Cudd (1999). "Finance degree programs and the issue of student preparedness." Journal of Education for Business, 74, 335-340.

32. Terpstra, D.E., E.J. Rozell, \& R.K. Robinson (1993). “The influence of personality and Psychology, 127, 375-389. 


\section{EXHIBIT 1: Attitude toward Business Ethics Questionnaire (ATBEQ)}

Reflect on the following statements about business attitudes. Indicate your position regarding each statement by circling the number which is closest to your view.
1. Strongly disagree
2. Disagree
3. Not sure
4. Agree
5. Strongly agree

1. The only moral of business is making money.

2. A person who is doing well in business does not have to worry about moral problems.

3. Every business person acts according to moral principles, whether he/she is aware of it or not.

4. Act according to the law, and you can't go wrong morally.

5. Ethics in business is basically an adjustment between expectations and the way people behave.

6. Business decisions involve a realistic economic attitude and not a moral philosophy.

7. Moral values are irrelevant to the business world.

8. The lack of public confidence in the ethics of business people is not justified.

9. "Business ethics" is a concept for public relations only.

10. The business world today is not different from what it used to be in the past. There is nothing new under the sun.

11. Competitiveness and profitability are independent values (existing on their own).

12. Conditions of a free economy will serve best the needs of society. Limiting competition can only hurt society and actually violates basic natural laws.

13. As a consumer when making a car insurance claim, I try to get as much as possible regardless of the extent of the damage.

14. While shopping at the supermarket, it is appropriate to switch price tags or packages.

15. As an employee, I take office supplies home; it doesn't hurt anyone.

16. I view sick days as vacation days that I deserve.

17. Employee wages should be determined according to the laws of supply and demand.

18. The main interest of shareholders is maximum return on their investment.

19. George X says of himself, "I work long, hard hours and do a good job, but it seems to me that other people are progressing faster. But I know my efforts will pay off in the end." Yes, George works hard, but he's not realistic.

20. For every decision in business the only question I ask is, "Will it be profitable?" If yes - I will act according; if not, it is irrelevant and a waste of time.

21. In my grocery store every week I raise the price of a certain product and mark it "on sale". There is nothing wrong with doing this.

22. A business person can't afford to get hung up on ideals.

23. If you want a specific goal, you have got to take the necessary means to achieve it.

24. The business world has its own rules.

25. A good business person is a successful business person.

26. I would rather have truth and personal responsibility than unconditional love and belongings.

27. True morality is first and foremost self-interested.

28. Self-sacrifice is immoral.

29. You can judge a person according to his work and his dedication.

30. You should not consume more than you produce. 